\title{
The Effect of Sports Science Students' Social Media Addictions on Redundant Purchasing Behavior
}

\section{Seckin Doganer ${ }^{1}$ Halil Erdem Akoglu}

1.2 Ankara University, Sports Sciences Faculty, Department of Sports Management, Ankara, Turkey. Email:_oganer@ankara.edu.trTel: +905062178015

Email:heakoglu@,ankara.edu.trTel:+90538409055s

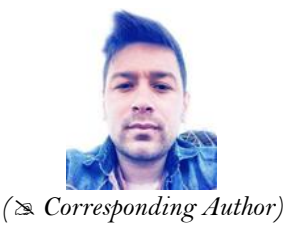

\begin{abstract}
The aim of this research is to determine the causes of redundant purchasing behavior of university students and the effects of social media usage on redundant purchasing behavior. Quantitative research method is used in the research and relational screening model is preferred. "Social media addiction" and "sustainable consumption behavior scale" were used in the research. The research group consists of 221 men and 181 women in total, 402 students who studying at Ankara University Faculty of Sport Sciences. In the research, the pre-control of the data was provided and the distribution of normality was examined primarily. From the parametric tests to the data that appear to provide normal distribution; t-Test, One-Way Anova and Correlation tests were applied. According to the findings, it was found that women had a high redundant purchase behavior compared to men. It has been determined that the use of credit cards increases redundant purchases in students and affects daily life. It was observed that unrestrained shopping perception is high among students who are not licensed athletes. As the high income students' redundant purchasing behavior is high, as the time spent on social media increases, social media addiction and redundant purchasing behavior also increase. As a conclusion, it is observed that consumption behaviors are closely related to social media addiction and sustainable consumption behaviors. The suggestions of the findings obtained were tried to be given in the research, including future research.
\end{abstract}

Keywords: Social media, Addiction, Purchase, Student, Behavior, Sustainable consumption.

Citation | Seckin Doganer; Halil Erdem Akoglu (2020). The Effect of Sports Science Students' Social Media Addictions on Redundant Purchasing Behavior. Asian Journal of Education and Training, 6(4): 616-626.

History:

Received: 15 July 2020

Revised: 5 October 2020

Revised: 5 October 2020

Accepted: 21 October 2020

Licensed: This work is licensed under a Creative Commons Attribution 3.0 License (oc)

Publisher: Asian Online Journal Publishing Group
Acknowledgement: Both authors contributed to the conception and design of the study.

Funding: This study received no specific financial support

Competing Interests: The authors declare that they have no conflict of interests.

Transparency: The authors confirm that the manuscript is an honest, accurate, and transparent account of the study was reported; that no vital features of the study have been omitted; and that any discrepancies from the features of the study have been omit
study as planned have been explained.

study as planned have been explained.
Ethical: This study follows all ethical practices during writing.

\section{Contents}

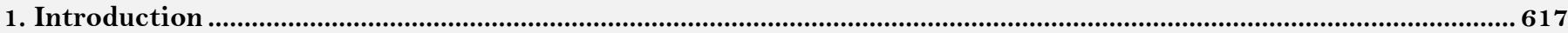

2. Method...

3. Results

620

4. Discussion.

5. Conclusion

References.. 


\section{Contribution of this paper to the literature}

This study contributes to existing literature by determining the causes of redundant purchasing behavior of university students and the effects of social media usage on redundant purchasing behavior.

\section{Introduction}

Nowadays, with the globalization, social media fields are increasingly reaching a significant potential all over the world. This potential development has manifested itself in social, psychological and knowledge-based practices, and has reached a high level in marketing and trade. Especially with social media, companies want to use online strategies to communicate with their potential customers are becoming an emerging trend in the global economy (Felix, Rauschnabel, \& Hinsch, 2017). The strategy of using social media affects all economic markets, from local companies to global companies, as well as causing projects to develop rapidly in this area ( $\mathrm{Si}, 2016)$. In 2019, the number of internet users worldwide increased by $9 \%$ annually to approximately 5.112 billion, while the number of social media users reached about 3.484 billion with an increase of $9 \%$ (Kemp, 2020). With this increase in the number of internet users, the use of social media has also increased and has evolved from an individual level to a useful marketing tool in the business world over the past decade (Zainal, Harun, \& Lily, 2017). Therefore, many organizations from various sectors nowadays use a social media account proactively to reach their potential and existing customers and keep up with changing consumer behavior (Ali Abdallah Alalwan, 2018; A. A. Alalwan, Rana, Algharabat, \& Tarhini, 2016; Kumar, Varma, Sangvikar, \& Pawar, 2020). Social media is defined by the user as a group of internet-based applications that allow content to be created and modified (Kaplan \& Haenlein, 2010).

Users can create content using various possibilities provided by social media websites such as pictures and videos and share a lot of information about the products, content and services of visually enriched brands (Erkan \& Evans, 2018). Social media, which takes place as the most important tool for sharing information and discussing this information nowadays also affects people's buying tendencies and decision making processes (Chen \& Lien, 2017). Social media, which is a fast and flexible tool for shopping, provides a convenient and easy shopping opportunity with online stores where consumers can reach 24 hours a day (Shankar, 2012). The fact that the use of social media leads to a global growth is important in terms of showing that these areas are also used by people as a means of purchasing behavior (Felix et al., 2017). As a matter of fact, according to the "Global Digital Report" published in 2019, it is stated that $84 \%$ of internet users use the internet to search for a product or service and $75 \%$ buy a product or service online within a month. Consumer buying behavior has been significantly affected by the emergence of information and communication technology (ICT) as well as the spread of social media. Consumers can now collect information through various media channels at every stage of the buying and decision-making process. For this reason, companies need to better understand changing customer purchasing behavior in order to create mutual value with consumers in social media use (Shah, Zahoor, \& Qureshi, 2019). Especially in recent years, companies differentiate social media marketing from other strategies as a low and effective marketing strategy to increase their turnovers (Lim, Radzol, Cheah, \& Wong, 2017). Current studies on the subject show that consumers are increasingly using social media to learn about unknown brands (Erkan \& Evans, 2018; Naylor, Lamberton, \& West, 2012; Schivinski \& Dabrowski, 2016; Shah et al., 2019).

The consumer, who thinks needs a product, realizes buying behavior in two options. The first option is a planned and controlled shopping. The second option is unplanned and out of control shopping. Although unplanned buying behavior provides the consumer with the peace of mind, it causes redundant product purchase, wastage and payment difficulties due to the preparation of the ground for unnecessary shopping (Erkmen \& Yuksel, 2008; Solomon, Bamossy, Askegaard, \& Hogg, 2006). Academic interest in connection between social media and consumer behavior has been steadily increasing in recent years (Frutos, Giones, \& Miralles, 2014). There is a steady increase in purchasing behavior and marketing research on social media (Pomirleanu, Schibrowsky, Peltier, \& Nill, 2013) and especially recently, researchers have been focusing on social media usage and online Mouth-to-Mouth Communication (E-WOM) They have shown that it has a positive effect (Alharbi, Aziz, Yusof, \& Hamid, 2020; Erkan \& Evans, 2018; Farzin \& Fattahi, 2018; Lam, Lau, Cheng, \& Wong, 2019; Tien, Rivas, \& Liao, 2019). Bolton et al. (2013) revealed that the majority of social media research is conducted in developed countries, predominantly in Europe and the United States (USA), while less research is conducted in developing economies. Many researchers have stated that social media and consumer behaviors should be handled in different contexts. Social media, which has taken place in our lives with the development of technology, has an inevitable effect on purchasing activities. However, not every purchasing activity is oriented towards need.

\subsection{Social Media Addiction}

According to the data of January 2020, approximately half of the world's population is active social media users. While people spend an average of 6 hours and 43 minutes a day on the internet, they also spend 2 hours and 24 minutes on social media (Kemp, 2020). The reasons for this augmentation are increasing the number of social media platforms day by day (Hawi \& Samaha, 2017). While Facebook has 1.95 billion active users from these social media platforms, Instagram has 925.5 million, Linkedin 663.3 million, Snapchat 381.5 million and Twitter 339.6 million active users (Kemp, 2020). Social media addiction is sometimes an expression used to refer to someone who spends a lot of time using Facebook, Twitter, Instagram or other social media platforms, and this time affects other aspects of daily life (Grau, Kleiser, \& Bright, 2019).

Social networking sites that many people think of as social media are defined as "any type of social interaction people have with the desire to control the impressions of other people" and have an important role in presenting / revealing themselves (Kaplan \& Haenlein, 2010). Thadani, Cheung, and Lee (2016) stated that the pathological and dependent use of social media is a relatively new topic and the symptoms of social media addiction attract researchers' attention. Some of these symptoms are noted as follows: Social media dominating users' behavior and thoughts, mood swings, tolerance (the use of social media should increase to maintain or gain priority positive emotion), withdrawal (ending social media use will lead to unpleasant feelings or emotions), conflict (social 
participation in media use will lead to conflicts in relationships, education, work and others) and repetition (tendency to return to previous forms of social media use after control or deprivation).

Research has shown that various online activities, such as constant online gaming and social media use, can be addictive to a particular group, especially adolescents and adults (Cheng \& Li, 2014; Kuss, Griffiths, Karila, \& Billieux, 2014; Ryan, Chester, Reece, \& Xenos, 2014). Social media sites are particularly important for Millennium college students, who have been determined to spend a lot of time online and use the Internet frequently for social purposes (Grau et al., 2019). Especially in developed and developing countries, the development of the Wi-Fi network and the fact that $60 \%$ to $95 \%$ of the young adults all have smart phones, and the rapid increase in the number of applications developed for smart phones are the factors that cause the growth of social media usage of people (Yang, Chen, Huang, Lin, \& Chang, 2017). One of the most important factors in the growth of internetrelated addictions is the widespread use of smartphones. Smartphones now offer an easy and more accessible way to access many different types of content (Gambling, gaming, shopping, social media) that may be dependent on potential individuals (Billieux, Maurage, Lopez-Fernandez, Kuss, \& Griffiths, 2015; Kuss \& Griffiths, 2017). Internet addiction is considered an increasing health problem in many parts of the world; The estimated dependency rates between $1.5 \%$ and $8.2 \%$ in the USA and Europe and up to $7 \%$ in some Asian countries are estimated (Weinstein \& Lejoyeux, 2010; Wölfling, Beutel, Dreier, \& Müller, 2014). In the literature, studies from different disciplines such as sociology and psychology on internet addiction and marketing have been seen in recent years (Al-Menayes, 2015; Blackwell, Leaman, Tramposch, Osborne, \& Liss, 2017; Bright, Grau, \& Kleiser, 2015; Griffiths \& Kuss, 2017; Hawi \& Samaha, 2017; Kircaburun, 2016; Longstreet \& Brooks, 2017; Savci \& Aysan, 2017; Turel, Brevers, \& Bechara, 2018).

\subsection{The Redundant Purchasing}

The purchasing decision process in consumer behavior begins with the emergence of a need. Firms acting as sales-oriented aim to initiate the purchasing decision process of the consumers by following a policy of making them feel needed on target consumers regarding the products they offer to the market. Consumers are exposed to firms' guidance on whether they really need a product (Yurtsever \& Çakmak, 2012). Consumers often make spontaneous and intuitively unplanned purchases after being exposed to stimuli such as price promotion, limited offer advertising and attractive product appearance. This type of purchase, called impulse purchase, has three main features: 1) unplanned, 2) the result of exposure to a stimulus, and 3) the "immediate" decision maker (Liu, Li, \& $\mathrm{Hu}, 2013)$. When customers go to a store to make certain purchases, they usually make unplanned purchases. There are four types of unplanned purchases (Stern, 1962):

(1) Pure impulse: These are purchases made only for hedonic reasons and are usually characterized by:

(a) Spontaneity.

(b) Strength, coercion and intensity.

(c) Excitement and revival.

(d) Ignoring the results (Rook, 1987).

(2) Reminder effect: A stimulus reminds the consumer to buy a product they need.

(3) Suggestion effect: The customer buys a product due to the promotion.

(4) Planned impulse: The customer purchases without any product (s) in mind.

While shopping in the physical world is often restricted by time and geographic location, online consumers can shop wherever and whenever they want, and so the number of products they probably buy with impulse is increasing. Clicking on the ads on the social media and accessing the store where the product is located can facilitate the unplanned redundant purchases of consumers (Koufaris, 2002). Beatty and Ferrell (1998) found that in-store screening behavior can impulsively increase the urge to buy. If online consumers are satisfied with online shopping and experience, they can screen more discoveries in the Web store, which can lead to redundant purchases.

Considering the aforementioned definitions in the literature, it is aimed to determine the causes of the redundant purchasing behavior and the effects of the use of social media on the redundant purchasing behavior. For this purpose, the theories in the literature were examined and the study was considered to be examined under "Flow Theory". Flow Theory; It is defined as "the whole of emotions created by the person to fully devote himself to this work while he is busy with any work, to focus on the action he is doing and to isolate himself from the world at the time" (Csikszentmihalyi, 1990). At the basis of the flow theory is a reward motivation that makes behavior constant and turns this process into a kind of "losing yourself or not knowing how time has passed. In addition to being defined as "activities and processes in which people act as if nothing else matters", it is also defined as "the total feeling that people feel when they act with collective participation" (Csikszentmihalyi, 1975). Studies to explain the flow experience may differ in itself when evaluated in terms of content. The research published by Hoffman and Novak (1996) on the stream has been an important start for the first time in online consumer behavior research and conceptualized the flow as a cognitive condition taking place on the web. Hoffman and Novak (1996) suggest that online streaming is a cognitive condition experienced during online navigation. Hoffman and Novak (1996) argue that the online shopping environment can bring some kind of flow situation, which leads to more online browsing and ultimately purchase. Smith and Sivakumar (2004) also suggest that the stream facilitates online behavior such as browsing, shopping and repurchasing. Novak, Hoffman, and Yung (2000) found that $47 \%$ of users experience internet streaming at some point. With the increase in computer use and the increase in communication services, online communication among people has improved and purchasing behavior has become easier and increased. For this reason, the researchers stated that consumers who are deeply immersed in a site that is visually appealing, entertaining, informative or useful, can experience the flow state mentioned in theory. 


\section{Method}

\subsection{Model of the Research}

They are quantitative methods, one of the scientific research types. Quantitative research method is seen as a method that allows the researcher to interpret the relationships between variables with meaningful data along with various proven measurement tools to achieve concrete results (Creswell, 2009). In the research, "correlational survey model” was preferred among general screening models in which individuals' opinions and attitudes about any case or event were examined and tried to be interpreted. The purpose of screening research is to make a description by taking a picture of the current situation related to the research subject (Büyüköztürk, Cakmak Kılıç, Akgün, Karadeniz, \& Demirel, 2017). Correlational survey model, on the other hand, is preferred as a method that does not describe the variables of the situation in the general screening models individually (singular), but also explains the change of the relationships between the variables (Mazlum \& Mazlum, 2017).

\subsection{Research Group}

While creating the research group, convenience sampling method, which is non-random, is used. Convenience sampling method is a non-random sampling method in which the sample section to be selected from the population is determined by the researcher's judgment. In convenience sampling, data are collected from the mainstream in the easiest, fastest and most economical way (Etikan, Musa, \& Alkassim, 2016). The research group of the study consisted of $402\left(\mathrm{~N}_{\text {men }}=221\right.$ and $\left.\mathrm{N}_{\text {women }}=181\right)$ university students studying at Ankara University Faculty of Sport Sciences. The average age of the participants was determined as $22.16 \pm 2.95$. The findings related to descriptive statistics are given in Table 1.

Table-1. Percentage distribution of participants' demographic information.

\begin{tabular}{|c|c|c|c|c|c|c|c|c|}
\hline Variant & Group & f & $\%$ & Total & $\overline{\mathbf{x}}$ & $\mathbf{S}$ & Least & Most \\
\hline Gender & $\begin{array}{l}\text { Women } \\
\text { Men }\end{array}$ & $\begin{array}{l}181 \\
221\end{array}$ & $\begin{array}{l}45,0 \\
55,0\end{array}$ & 402 & & & & \\
\hline Grade & $\begin{array}{l}\text { 1st Grade } \\
\text { 2nd Grade } \\
\text { 3rd Grade } \\
\text { 4th Grade }\end{array}$ & $\begin{array}{c}46 \\
107 \\
122 \\
127 \\
\end{array}$ & $\begin{array}{l}11,4 \\
26,6 \\
30,3 \\
31,6 \\
\end{array}$ & 402 & & & & \\
\hline Family Income Status & $\begin{array}{l}0-2000 \\
2001-3500 \\
3501-5000 \\
5001 \text { and }+ \\
\end{array}$ & $\begin{array}{c}50 \\
115 \\
128 \\
109 \\
\end{array}$ & $\begin{array}{l}12,4 \\
28,6 \\
31,8 \\
27,1 \\
\end{array}$ & 402 & & & & \\
\hline Credit Card Usage Status & $\begin{array}{l}\text { Yes } \\
\text { No }\end{array}$ & $\begin{array}{l}234 \\
168\end{array}$ & $\begin{array}{l}58,2 \\
41,8 \\
\end{array}$ & 402 & & & & \\
\hline $\begin{array}{l}\text { Time spent on social media } \\
\text { in a day }\end{array}$ & $\begin{array}{l}\text { Lessthan } 1 \text { hour } \\
1-2 \text { hours } \\
3-5 \text { hours } \\
\text { More than } 6 \text { hours }\end{array}$ & $\begin{array}{c}27 \\
122 \\
199 \\
54 \\
\end{array}$ & $\begin{array}{c}6,7 \\
30,3 \\
49,5 \\
13,4 \\
\end{array}$ & 402 & & & & \\
\hline Licensed Athletics Status & $\begin{array}{l}\text { Yes } \\
\text { No }\end{array}$ & $\begin{array}{l}195 \\
207\end{array}$ & $\begin{array}{l}48,5 \\
51,5\end{array}$ & 402 & & & & \\
\hline \multicolumn{2}{|l|}{ Age } & & & 402 & 22,16 & 2,95 & 18,00 & 48,00 \\
\hline \multicolumn{2}{|l|}{ Social Media Addiction Scale } & & & 402 & 65,41 & 20,70 & 24,00 & 116,00 \\
\hline
\end{tabular}

$221(55.0 \%)$ of the university students constituting the study group of the research are men and $181(45 \%)$ are women. 3rd grade students constitute $127(31.6 \%)$ of the students and $128(31.8 \%)$ of the family income is between 3501-5000 TL. In addition, 234 (58.2\%) of the students were found to use credit cards. It is seen that the vast majority use social media $(\mathrm{N}=383)$ and the majority $(\mathrm{N}=199 ; 49.5 \%)$ spend $3-5$ hours a day on social media. It was determined that $207(51.5 \%)$ of the participants were licensed athletes, while $195(48.5 \%)$ were not licensed athletes. It is seen that the social media addiction levels of the participants are at medium levels $(\mathrm{X}=65.41 \pm$ 20.70).

\subsection{Data Collection Tool}

As the data collection tool, primarily, the personal information form containing the demographic information of the participants was applied to the participants, and secondly, "Social Media Addiction Scale" and "Sustainable Consumption Behavior Scale" were used.

Personal Information Form: In this section, there are 8 items related to the personal information of the participants. These variables are; age, gender, class, family income status, credit card usage status, time spent on social media daily and licensed sports status.

Social Media Addiction Scale: The measurement tool, developed by Firat and Barut (2018) consisting of a total of 24 items, consists of 2 sub-dimensions Lower dimensions; It occurs as "uncontrolling" and "affecting / depriving daily life". The measurement tool, which has a 5-point evaluation in Likert type, is scored as "Never (1)", "Rare (2)", "Sometimes (3)", "Generally (4)", and "Always (5)". The total score that can be obtained from the SMDS is 24 to 120 ; The total score that can be obtained for the withdrawal dimension varies between 14 and 70 , and for the impact on daily life / uncontrolled dimension between 10 and 50. It can be interpreted that as the score obtained by individuals from SMDS increases, their social media addiction increases.

Sustainable Consumption Behavior Scale: The measurement tool consisting of 17 items in total which is developed by Doğan, Bulut, and Kökalan Cimrın (2015) consists of 4 sub-dimensions. Sub dimensions; Environmental Awareness is defined as Redundant Purchase, Savings and Reusability. In this study, only the "Redundant Purchase" sub-scale, which consists of 5 items, was used. The measurement tool, which has a 5-point evaluation in Likert type, is scored as "Never (1)", "Rare (2)", "Sometimes (3)", "Generally (4)", and "Always (5)". In the case of 
Redundant Purchase, the situation is the opposite. Sustainability of consumption increases as the score given to the items of this dimension decreases.

\subsection{Collection of Data}

The scale questions were applied in the form of one-on-one questions and answers, face-to-face discussion with the participants during the data collection phase. The individuals who participated in the study were informed by the researcher about the importance of the study and their importance for this study, and in this context, it was stated that giving answers that reflect the correct and current situation will affect the reality of the research. For this reason, it was assumed that the individuals participating in the research responded realistically to the scale applied. Of the 450 questionnaires distributed, 420 were collected. Eight of these questionnaires, which were analyzed, were not evaluated because they were filled in incorrectly or incompletely by the surveyors. As a result, 402 questionnaires were accepted as valid and evaluated.

\subsection{Data Analysis}

In order to test whether the obtained data shows normal distribution, skewness and kurtosis analyzes were applied and it was understood that the data showed normal distribution as a result of these tests. Parametric tests (T-test, One-Way Anova test, Pearson Correlation analysis) were applied on the normally distributed data. To identify the different group in the One-Way Anova test, the Tukey test was used in the Post-Hoc tests. Cronbach's Alpha reliability coefficients of the scales were examined and it was determined that all values were above 0.70. In the normality distribution measurements, when skewness values are between -2 and +2 and kurtosis values are between -2 and +2 , then the data is identified as normally distributed (George \& Mallery, 2010). The normality test results and Cronbach's Alpha values of the data are given in Table 2.

Table-2. Normality analysis and cronbach's alpha results.

\begin{tabular}{|c|c|c|c|c|c|c|}
\hline Scales & Sub Dimensions & Items & Average & Skewness & Kurtosis & $\mathbf{A}$ \\
\hline 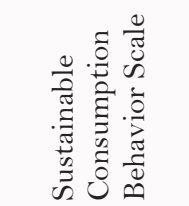 & Redundant Purchase & 5 & 2,67 & ,259 &,- 590 & ,83 \\
\hline \multirow{2}{*}{ 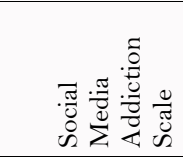 } & Uncontrolling & 14 & 2,40 & ,225 &,- 918 & ,94 \\
\hline & Affecting Daily Life/Deprivation & 10 & 2,95 &,- 084 &,- 652 & ,92 \\
\hline
\end{tabular}

\section{Results}

In this section, from descriptive statistics, t-Test, One-Way Anova analysis and correlation (pearson) analysis are included.

Table-3. T-Test analysis results regarding gender variable.

\begin{tabular}{|c|c|c|c|c|c|c|c|}
\hline Sub Dimensions & Gender & $\mathbf{N}$ & $\overline{\bar{x}}$ & $\mathbf{S}$ & sd & $t$ & $\mathrm{p}^{*}$ \\
\hline Redundant Purchase & $\begin{array}{c}\text { Women } \\
\text { Men }\end{array}$ & $\begin{array}{l}181 \\
221 \\
\end{array}$ & $\begin{array}{l}2,79 \\
2,57 \\
\end{array}$ & $\begin{array}{l}0,92 \\
0,93 \\
\end{array}$ & 400 & 2,415 & 0,01 \\
\hline Uncontrolling & $\begin{array}{c}\text { Women } \\
\text { Men }\end{array}$ & $\begin{array}{l}181 \\
221 \\
\end{array}$ & $\begin{array}{l}3,03 \\
2,88 \\
\end{array}$ & $\begin{array}{l}0,90 \\
0,88 \\
\end{array}$ & 400 & 1,615 & 0,10 \\
\hline Affecting Daily Life/Deprivation & $\begin{array}{c}\text { Women } \\
\text { Men }\end{array}$ & $\begin{array}{l}181 \\
221\end{array}$ & $\begin{array}{l}2,43 \\
2,38\end{array}$ & $\begin{array}{l}0,95 \\
0,91\end{array}$ & 400 & 0,522 & 0,60 \\
\hline
\end{tabular}

Note: $\mathrm{P}<0,05^{*}$.

When Table 3 is analyzed, a statistically significant difference was found in favor of women students $\left(\mathrm{X}_{\text {women }}=\right.$ $2,79 ; \mathrm{p}<0,05)$ in the size of redundant purchase by gender. The average scores of women redundant purchase was found higher than men. There was no statistically significant difference in social media use scale sub-dimensions according to gender $(\mathrm{p}<0.05)$.

\begin{tabular}{|c|c|c|c|c|c|c|c|}
\hline Sub Dimensions & Credit Card Usage & $\mathbf{N}$ & $\overline{\bar{x}}$ & $\overline{\mathbf{S}}$ & sd & $\bar{t}$ & p* \\
\hline Redundant Purchase & $\begin{array}{l}\text { Yes } \\
\text { No }\end{array}$ & $\begin{array}{l}234 \\
168\end{array}$ & $\begin{array}{l}2,75 \\
2,55\end{array}$ & $\begin{array}{l}0,92 \\
0,95\end{array}$ & 400 & 2,150 & 0,03 \\
\hline Uncontrolling & $\begin{array}{l}\text { Yes } \\
\text { No }\end{array}$ & $\begin{array}{l}234 \\
168\end{array}$ & $\begin{array}{l}3,00 \\
2,87\end{array}$ & $\begin{array}{l}0,84 \\
0,96\end{array}$ & 400 & 1,408 & 0,16 \\
\hline Affecting Daily Life/Deprivation & $\begin{array}{l}\text { Yes } \\
\text { No }\end{array}$ & $\begin{array}{l}234 \\
168\end{array}$ & $\begin{array}{l}2,49 \\
2,28\end{array}$ & $\begin{array}{l}0,91 \\
0,94\end{array}$ & 400 & 2,231 & 0,02 \\
\hline
\end{tabular}

In Table 4, the results of the t-test analysis related to the sub-dimensions of the Redundant Purchase Scale and Social Media Usage Scale according to the students' credit card use status variable are given. When the findings were analyzed, a statistically significant difference was found in terms of students' redundant purchase average scores and credit card use status $(\mathrm{p}<0.05)$ and this difference was in favor of students using credit cards $\left(\mathrm{X}_{\text {yes }}=\right.$ 2.75; $\mathrm{p}<0.05)$ differentiated. When the average scores of the credit card use status of the students and the Social Media Usage Scale sub-dimensions were examined, no statistically significant difference was found in the "uncontrolling" sub-dimension, but a statistically significant difference was observed in the "affecting the daily life / deprivation" sub-dimension. It was determined that the difference was caused by students using credit cards $\left(\mathrm{X}_{\text {yes }}\right.$ 
$=2.49 ; \mathrm{p}<0.05)$. According to these findings, it is seen that students who use credit cards have higher redundant purchasing behavior.

Table-5. T-Test analysis results related to the licensed athletic variable.

\begin{tabular}{|c|c|c|c|c|c|c|c|}
\hline Sub Dimensions & Licensed athletic & $\mathbf{N}$ & $\overline{\boldsymbol{x}}$ & $\mathbf{S}$ & sd & $t$ & $\mathbf{p}^{*}$ \\
\hline Redundant Purchase & $\begin{array}{l}\text { Yes } \\
\text { No }\end{array}$ & $\begin{array}{l}195 \\
207\end{array}$ & $\begin{array}{l}2,63 \\
2,70\end{array}$ & $\begin{array}{l}0,90 \\
0,97\end{array}$ & 400 & $-0,704$ & 0,48 \\
\hline Uncontrolling & $\begin{array}{l}\text { Yes } \\
\text { No }\end{array}$ & $\begin{array}{l}195 \\
207 \\
\end{array}$ & $\begin{array}{l}2,84 \\
3,05\end{array}$ & $\begin{array}{l}0,90 \\
0,88 \\
\end{array}$ & 400 & $-2,259$ & 0,02 \\
\hline Affecting Daily Life/Deprivation & $\begin{array}{l}\text { Yes } \\
\text { No }\end{array}$ & $\begin{array}{l}195 \\
207\end{array}$ & $\begin{array}{l}2,31 \\
2,49\end{array}$ & $\begin{array}{l}0,95 \\
0,90\end{array}$ & 400 & $-1,844$ & 0,06 \\
\hline
\end{tabular}

In Table 5, the findings regarding the Sub-Dimensions of Redundant Purchase Scale and Social Media Usage Scale according to the variable of being a licensed athlete of the students were examined. A statistically significant difference was found among the social media addiction sub-dimensions of the students in terms of uncontrolling average scores and licensed sports status, and this difference was observed to differ in favor of non-licensed athletes $\left(\mathrm{X}_{\mathrm{no}}=3.05, \mathrm{p}<0.05\right)$. No statistically significant difference was found between the licensed athletics variable and the average scores of redundant purchasing and affecting daily life / deprivation $(\mathrm{p}<0.05)$.

\begin{tabular}{|c|c|c|c|c|c|c|c|c|}
\hline Sub Dimensions & Income Status & $\overline{\mathbf{N}}$ & $\overline{\bar{x}}$ & $\mathbf{S}$ & sd & $\mathbf{F}$ & $\mathrm{p}^{*}$ & LSD \\
\hline \multirow{4}{*}{ Redundant Purchase } & 1. $0-2000$ & 50 & 2,30 & 0,81 & \multirow{4}{*}{$\begin{array}{c}3 \\
398 \\
401\end{array}$} & \multirow{4}{*}{6,735} & \multirow{4}{*}{0,00} & \multirow{4}{*}{$4>1,2,3$} \\
\hline & 2. 2001-3500 & 115 & 2,55 & 0,92 & & & & \\
\hline & $3.3501-5000$ & 128 & 2,67 & 0,91 & & & & \\
\hline & $4.5001+$ & 109 & 2,95 & 0,96 & & & & \\
\hline \multirow{4}{*}{ Uncontrolling } & 1. 0-2000 & 50 & 2,21 & 0,85 & \multirow{4}{*}{$\begin{array}{c}3 \\
398 \\
401\end{array}$} & \multirow{4}{*}{2,483} & \multirow{4}{*}{0,06} & \multirow{4}{*}{-} \\
\hline & $2.2001-3500$ & 115 & 2,40 & 0,92 & & & & \\
\hline & $3.3501-5000$ & 128 & 2,32 & 0,91 & & & & \\
\hline & $4.5001+$ & 109 & 2,59 & 0,98 & & & & \\
\hline \multirow{4}{*}{ Affecting Daily Life/Deprivation } & 1. $0-2000$ & 50 & 2,87 & 0,79 & \multirow{4}{*}{$\begin{array}{c}3 \\
398 \\
401\end{array}$} & \multirow{4}{*}{1,510} & \multirow{4}{*}{0,21} & \multirow{4}{*}{ - } \\
\hline & 2. 2001-3500 & 115 & 2,95 & 0,91 & & & & \\
\hline & $3.3501-5000$ & 128 & 2,85 & 0,91 & & & & \\
\hline & $4.5001+$ & 109 & 3,09 & 0,90 & & & & \\
\hline
\end{tabular}

Note: $\mathrm{P}<0,05^{*}$

In Table 6, a statistically significant difference was found between the income levels of the students and the average of the redundant purchase $(\mathrm{p}<0.05)$. As a result of the LSD test conducted to determine which groups the difference originated from, it was concluded that the students whose family income status was higher than 5001 had higher average scores than other groups $\left(\mathrm{X}_{5001}+=2.95 ; \mathrm{p}<0.05\right)$. There was no statistically significant difference between family income status variable and Social Media Addiction Scale sub-dimensions $(\mathrm{p}<0.05)$.

\begin{tabular}{|c|c|c|c|c|c|c|c|c|}
\hline Sub Dimensions & Time spent on Soc. Med. & $\mathbf{N}$ & $\bar{x}$ & $\mathbf{S}$ & sd & $\mathbf{F}$ & $\mathrm{p}^{*}$ & LSD \\
\hline \multirow{4}{*}{ Redundant Purchase } & a-Less than 1 hour & 27 & 1,96 & 0,92 & \multirow{4}{*}{$\begin{array}{c}3 \\
398 \\
401\end{array}$} & \multirow{4}{*}{13,819} & \multirow{4}{*}{0,00} & \multirow{4}{*}{$d>a, b, c$} \\
\hline & b-1-2 hours & 122 & 2,43 & 0,90 & & & & \\
\hline & c-3-5 hours & 199 & 2,79 & 0,85 & & & & \\
\hline & d-More than 6 hours & 54 & 3,10 & 1,01 & & & & \\
\hline \multirow{4}{*}{ Uncontrolling } & a-Less than 1 hour & 27 & 1,50 & 0,74 & \multirow{4}{*}{$\begin{array}{c}3 \\
398 \\
401\end{array}$} & \multirow{4}{*}{36,006} & \multirow{4}{*}{0,00} & \multirow{4}{*}{$d>a, b, c$} \\
\hline & b-1-2 hours & 122 & 1,98 & 0,76 & & & & \\
\hline & c-3-5 hours & 199 & 2,61 & 0,86 & & & & \\
\hline & d-More than 6 hours & 54 & 3,04 & 0,87 & & & & \\
\hline \multirow{4}{*}{ Affecting Daily Life/Deprivation } & a-Less than 1 hour & 27 & 1,80 & 0,80 & \multirow{4}{*}{$\begin{array}{c}3 \\
398 \\
401\end{array}$} & \multirow{4}{*}{48,230} & \multirow{4}{*}{0,00} & \multirow{4}{*}{$\mathrm{d}>\mathrm{a}, \mathrm{b}, \mathrm{c}$} \\
\hline & b-1-2 hours & 122 & 2,54 & 0,77 & & & & \\
\hline & c-3-5 hours & 199 & 3,19 & 0,76 & & & & \\
\hline & d-More than 6 hours & 54 & 3,54 & 0,76 & & & & \\
\hline
\end{tabular}

In Table 7, the findings related to the sub-dimensions of the Redundant Purchase Scale and Social Media Usage Scale according to the time variable spent on the social media of the students are examined. A statistically significant difference was found between the Redundant Purchase Scale and the time variable that students spent on social media, and the LSD test conducted to determine this difference showed that the mean scores of the group who spent more than 6 hours in social media were high $\left(\mathrm{X}_{\text {redundant purchase }}=3.10 ; \mathrm{p}<0.05\right)$.

Students' social media addiction sub-dimensions were uncontrolled $\left(\mathrm{X}_{\text {uncontrolling }}=3.04 ; \mathrm{p}<0.05\right)$ and their average scores on affecting / deprivation of daily life $\left(\mathrm{X}_{\text {deprivation }}=3.54 ; \mathrm{p}<0.05\right)$ were statistically significant. There was a significant difference. As a result of the LSD test conducted to determine which groups the difference originated from, it was observed that the average scores of the group who spent more than 6 hours in both subdimensions on social media were high.

According to Table 8, a statistically low negative relationship was found between the ages of the students and the dimensions of uncontrolling and daily life affecting / deprivation among the sub-dimensions of the redundant purchase and social media addiction scale $(\mathrm{p}<0.05)$. In addition, a statistically positive relation was found between the time spent on social media and family income status and the dimensions of uncontrolling and daily affecting / deprivation among the sub-dimensions of redundant purchasing and social media addiction scale $(\mathrm{p}<0.05)$. 
Table-8. Correlation analysis table regarding demographic variables and scales.

\begin{tabular}{l|c|c|c}
\hline Demographic Variables & Redundant Purchase & Uncontrolling & Affecting Daily Life/Deprivation \\
\hline Age &,$- 146^{*}$ &,$- 180^{* *}$ &,$- 231^{* *}$ \\
\hline Time spent on social media &, $357^{* *}$ &, $657^{* *}$ &, $590^{* *}$ \\
\hline Family income status &, $275^{* *}$ &, $173^{* *}$ &, $223^{* *}$ \\
\hline Redundant Purchase & - &, $621^{* *}$ &, $526^{* *}$ \\
\hline
\end{tabular}

As a final, a positive relationship was found between the social media addiction scale sub-dimensions of uncontrolling and daily life affecting / deprivation levels and redundant purchasing levels. In other words, as the social media addiction of the students increases, the level of redundant purchases increases.

\section{Discussion}

In the research, where the effects of social media addictions on consumers' redundant purchasing behaviors were examined, significant differences were found regarding the sub-dimensions of the scales. When the findings obtained are analyzed in terms of gender variable, no statistically significant difference was detected in the perception of social media addiction, but a meaningful difference was observed in favor of women in the perception of "redundant purchase" that includes sustainable consumption behaviors This situation is important for women to show more redundant purchase behaviors than men via social media. It is also emphasized in similar studies that women can access social media tools more easily than men and use these tools as a personalized area for various purposes effectively (McGregor, Lawrence, \& Cardona, 2017). When the literature is analyzed, it is seen that men brand loyalty is higher, so that men are less affected by social pressures than women, and they have a high tendency to purchase against the product they are interested in Rialti, Zollo, Pellegrini, and Ciappei (2017). The result can be seen as important because it shows that women are less selective in consumption behavior than men and therefore they keep their redundant purchasing behavior highIn another research that reveals the difference between the use of social media between women and men, it is seen that women prefer these networks to protect their close social relationships, while men use these networks to conduct research and obtain information on topics they are interested in Krasnova, Veltri, Eling, and Buxmann (2017). The findings obtained from the exemplified researches are similar to our research results.

According to the results of the research, it was determined that students whose using credit cards had higher redundant purchasing behaviors. The use of credit cards is a preferred payment method, especially in web-based shopping, and it allows shopping to be make easier, but this type of convenience brings with it the risk of spending too much (Aslanoğlu \& Korga, 2017). In a research conducted with university students, it was found that men tend to borrow more frequently than women when using credit cards. This situation was explained by the researchers that the risk factor in men is more dominant than women. However, when the results of the research are analyzed, it is determined that women are in a longer-term get into debt compared to men (Santos., Mendes-Da, Flores, \& Norvilitis, 2016). The fact that women are in a long-term debt is similar to our redundant purchases for women. In a similar research on credit card expenditures, it was found that credit card debt, calculated by students in the last decade, was worrying. The research shows that environmental factors, the working environment and the characteristic structure lead the person to financial behavior and eventually lead to credit card debt (Hancock, Jorgensen, \& Swanson, 2013). It was also emphasized in a different study that social media strengthens purchasing behavior in individuals and it is seen that consumers are affected by their social environment very much and they are influenced by stimuli from this environment and they tend to purchase behavior without waiting (Thoumrungroje, 2014). Therefore, the convenience of using credit cards in shopping can be combined with positive comments from social media, thus accelerating the buying behavior in individuals. These results are similar to our research results.

A significant difference was found in the "uncontrolling" sub-dimension between the licensed athlete status of the students and the scale of social media addiction It was observed that the difference was caused by students who were not licensed athletes. This shows that students who are not licensed athletes can be affected by sociopsychological factors. University students especially pay attention to how they develop socially in campus. This situation, which is also mentioned in the social identity theory, is defined as the identification of individuals with various symbols to make themselves more social (Kim \& Kim, 2019). These symbols and social comparisons, which are a reflection of the individual's actions, intentions or attitudes, the person sees himself in the groups he wants to belong to, and this behavior can be determined by providing psychological discrimination (Martyn, Fowler, Kropp, Oja, \& Bass, 2019).The right social media use of the firms will attract their customers, who are seeking symbolic pursuits, as well as the opportunity to make financial gain from this selectivity (Nevin et al., 2017). In a similar research, people's sportive purchasing levels were examined and it was found that purchasing behavior was significantly affected against products with emotional commitment. The belief in symbolic belonging, especially mentioned in the social identity theory, has positively affected the purchasing behavior of people at the fan level, and over time, this behavior has been observed to decrease with age, social environment or similar reasons (Eskiler, Altunişik, \& Ayhan, 2019).

In the research, it was observed that the students with high income status had higher purchase points than the students with low income status. It is accepted that the perception of social identity develops with social networks and this social development turns into buying behavior It is observed that individuals with a wide social environment and high purchasing power transform the social connections they maintain through such networks into product analysis or purchasing behavior (Wang, 2017). At the same time, it has been observed that the use of well-known or rich people in the promotion of the accepted brands provides a kind of reliability and loyalty between the product and the buyer (Jamil \& Rameez, 2014). This type of strategies suggests that shopping from online platforms can turn into redundant purchases. In a similar study on consumer perception in digital marketing, when the amount spent on online shopping is analyzed, it is found that those with high income do more shopping than those with low income (Koçarslan \& Kılınç, 2019). While these results are similar to our research results, different results are also seen in the literature. For example, in a research on social media and purchasing 
level, it was determined that the income status does not make a significant difference on the perception of purchasing (Meydan \& Tunca, 2019). In a similar study on uncontrolled purchasing trends, unlike the results we have obtained, no relation between monthly income level and uncontrolled purchasing tendency has been determined (Yoldaş \& Akın, 2019).

In the research, it has been determined that the students who spend more than 6 hours on social media have high scores on variables such as redundant purchasing, uncontrolling and affecting daily life. Research shows that technology affects every area in daily life, from business environment to personal relationships, and especially the use of social media reveals a distraction and attention deficit that causes stress together with internet addiction (Brooks, Longstreet, \& Califf, 2017). At the same time, social media addiction has recently revealed a kind of stress factor that has been translated as "fear of missing out". This factor can be characterized as "the desire to stay in touch with what others do" (Swar \& Hameed, 2017). Fear of losing social media access may cause mood disorders such as stress, anxiety, depression and loss of control in students (Elhai, Hall, \& Erwin, 2018). Thus, these situations, which are also seen in the literature, may lead to negative effects on daily life, uncontrolling or redundant purchasing behavior. In a study examining the social media addiction levels of university students, it was observed that the social media addiction levels increased as the time allocated by the participants increased to social media (Aktan, 2018). In another study on the time spent on social media mentions that when the use of social media is normal during adolescence but the time spent on these platforms cannot be controlled, it can create an uncontrolled process in individuals. The research suggests that self-directed training in individuals may be beneficial for this period to be used effectively (Coyne, Padilla-Walker, Holmgren, \& Stockdale, 2019). These data obtained from the literature are similar to our research results, but in a study examining the social benefit, addiction and satisfaction feeling about the use of social media, different results are seen. According to research results, individuals use online social platforms for more than 3 hours a day and can get their basic and social needs both from here. Social media addiction levels of the participants were found to be high, but it was found that this turned into a habit that creates a sense of satisfaction for both genders (Santoso \& Oetomo, 2019).

\section{Conclusion}

The constant renewal of social media areas and their facilitation of information sharing and shopping have enabled people to make these platforms a part of their lives. The development of the social environment has enabled the commercial activities to serve through these areas. Companies have come closer to their potential customers through social media and developed various strategies to promote their products. These strategies created a sustainable consumption behavior by social media users, causing them to observe the effects of the products followed on social media. The fact that users examine the reviews about the product and exhibit purchasing behavior within this framework causes companies to constantly review their strategies. The main sales policies of these types of companies have been the promotion of product promotions, especially on liked or popular characters, evaluating negative comments, updating products, and as a result, introducing marketing strategies focused on user satisfaction.

The purchasing, following-up, or suggesting behaviors of the students on social media necessitated them to spend long hours in these areas. Especially women shopping, taking into account the stimuli coming from their social circles, sometimes led them to a redundant purchasing behavior. Brand loyalty, which is more common in men, and the feeling of taking more risks than women, have caused them to make purchases that can exceed their income. This type of shopping is due to the widespread use of credit cards and the convenience of shopping on social media, causing uncontrolled shopping in users. When the time spent on social media is added to this, a situation that affects daily life can arise and create negative emotional states. However, research suggests that this type of purchases will increase and become easier in the future. It is observed that especially the young population, which is more intertwined with social media, is satisfied with these developments, and even transformed the gains from such platforms into positive habits. As a result, it is thought that social media platforms will continue to progress with the development of internet and technology and increase the buying behavior of students in parallel with the current strategies of the companies. If the social media addiction that may arise in these environments can be controlled by various techniques and the feeling of uncontrolling can be reduced, it will also be possible for students to display a more effective and sustainable consumption behavior without affecting their daily lives.

Considering the results obtained from the research; When the person turns himself to a job, by focusing on this job, it is seen that the situations such as turning into a time that can affect his daily life and as a result of having uncontrolled coincide with the explanations mentioned in the flow theory. Increasing social communication with internet applications and facilitating purchasing behavior can be considered as the increase of motivation sources mentioned in theory. As this situation affects all students, it is seen that motivation perception is different in students depending on gender. The flow status can also be considered as an important indicator of the financial uncontrolled experience of the students using social media.

\section{Suggestions}

It is frequently explained by researchers that the time spent on social media decreases or the topics of interest change as the age progresses. In this case, it is expected that the time spent by the students on social media does not turn into uncontrolling, redundant purchasing or not being able to do their daily business. Therefore, considering that this process is a normal development and need process, various informative or preventive strategies can be used by family and educators. In particular, keeping financial expenditures under control by the family is important for ensuring a sustainable consumption behavior as well as preventing unnecessary expenditure. It can also be thought during this process that students gain a sense of self-sufficiency, manage their search for social identity and reduce dependencies.

"Social media addiction" and "sustainable consumption behavior scale" were used in the research. In similar studies in the future, scales can be expanded and different levels of perception can be measured. In this sense, scales belonging to the branches of sociology and psychology can be used. At the same time, qualitative research can be 
created under different theories. This type of research is important to better reflect the user experience. The research is limited to a single city, but different cities and different groups may be preferred in future research.

\section{References}

Aktan, E. (2018). Investigation of social media addiction levels of university students according to various variables. Erciyes Communication Journal, 5(4), 405-421.

Al-Menayes, J. J. (2015). Dimensions of social media addiction among university students in Kuwait. Psychology and Behavioral Sciences, 4(1), 23-28.Available at: https://doi.org/10.11648/j.pbs.20150401.14.

Alalwan, A. A. (2018). Investigating the impact of social media advertising features on customer purchase intention. International Journal of Information Management, 42, 65-77.Available at: https://doi.org/10.1016/j.ijinfomgt.2018.06.001.

Alalwan, A. A., Rana, N. P., Algharabat, R., \& Tarhini, A. (2016). A systematic review of extant literature in social media in the marketing perspective. Paper presented at the Conference on e-Business, e-Services and e-Society.

Alharbi, M. K., Aziz, Y. A., Yusof, R. N. R., \& Hamid, A. B. A. (2020). Moderating role of trust between eWOM communication and purchase intention. Journal of Chemical Information and Modeling, 1(1), 44-53.

Aslanoğlu, S., \& Korga, S. (2017). Credit card usage and compulsive purchase: An application in the province of kirkale. Journal of Business ResearchTurk, 9(1), 148-165.Available at: 10.20491/isarder.2017.239.

Beatty, S. E., \& Ferrell, M. E. (1998). Impulse buying: Modeling its precursors. Journal of Retailing, 74(2), 169-191.Available at: https://doi.org/10.1016/s0022-4359(98)90009-4.

Billieux, J., Maurage, P., Lopez-Fernandez, O., Kuss, D. J., \& Griffiths, M. D. (2015). Can disordered mobile phone use be considered a behavioral addiction? An update on current evidence and a comprehensive model for future research. Current Addiction Reports, 2(2), 156-162.Available at: https://doi.org/10.1007/s40429-015-0054-y.

Blackwell, D., Leaman, C., Tramposch, R., Osborne, C., \& Liss, M. (2017). Extraversion, neuroticism, attachment style and fear of missing out as predictors of social media use and addiction. Personality and Individual Differences, 116, 69-72.Available at: https://doi.org/10.1016/j.paid.2017.04.039.

Bolton, R. N., Parasuraman, A., Hoefnagels, A., Migchels, N., Kabadayi, S., Gruber, T., \& Solnet, D. (2013). Understanding generation Y and their use of social media: A review and research agenda. Journal of Service Management, 24(3), 245-267.

Bright, L., Grau, S. L., \& Kleiser, S. B. (2015). Thumbs downto facebook? Exploring social media addiction among millennials using the consumption continuum framework. Paper presented at the In American Academy of Advertising Conference Proceedings (Online). American Academy of Advertising.

Brooks, S., Longstreet, P., \& Califf, C. (2017). Social media induced technostress and its impact on Internet addiction: A distraction-conflict theory perspective. AIS Transactions on Human-Computer Interaction, 9(2), 99-122.Available at: https://doi.org/10.17705/1 thci.00091.

Büyüköztürk, Ş., Cakmak Kılıç, E., Akgün, Ö. E., Karadeniz, Ş., \& Demirel, F. (2017). Scientific research methods. Ankara: Pegem.

Chen, C., \& Lien, N. (2017). Social media and marketing effectiveness. Asia Pacific Management Revierw, 22(1), 1-14.Available at: 10.1016/j.apmrv.2017.02.002.

Cheng, C., \& Li, A. Y. (2014). Internet addiction prevalence and quality of (real) life: A meta-analysis of 31 nations across seven World regions. Cyberpsychology, Behavio rand Social Networking, 17, 755-760.Available at: https://doi.org/10.1089/cyber.2014.0317.

Coyne, S. M., Padilla-Walker, L. M., Holmgren, H. G., \& Stockdale, L. A. (2019). Instagrowth: A longitudinal growth mixture model of social media time use across adolescence. Journal of Research on Adolescence, 29(4), 897-907.Available at: https://doi.org/10.1111/jora.12424.

Creswell, J. W. (2009). Research design: Qualitative, quantitati veand mixed methods approaches (3rd ed.). London: Sage Press.

Csikszentmihalyi, M. (1990). Flow: Thepsychology of optimal experience. New York: Harper \& Row.

Csikszentmihalyi, M. (1975). Beyond boredom and anxiety. San Francisco, CA: Jossey-Bass.

Doğan, O., Bulut, Z. A., \& Kökalan Cimrın, F. (2015). A scale development study for measuring the sustainable consumption behavior of individuals. Atatürk University Journal of Economics and Administrative Sciences, 29(4), 659-678.

Elhai, J. D., Hall, B. J., \& Erwin, M. C. (2018). Emotion regulation's relationships with depression, anxiety and stress due to imagined smartphone and social media loss. Psychiatry Research, 261, 28-34.Available at: https://doi.org/10.1016/j.psychres.2017.12.045.

Erkan, I., \& Evans, C. (2018). Social media or shopping websites? The influence of eWOM on consumers' online purchase intentions. Journal of Marketing Communications, 24(6), 617-632.Available at: https://doi.org/10.1080/13527266.2016.1184706.

Erkmen, T., \& Yuksel, C. A. (2008). A study on investigation of demographic and sociocultural characteristics of consumers with shopping behavior patterns. Ege Academic Review, 8(2), 683-727.

Eskiler, E., Altunişik, R., \& Ayhan, C. (2019). Determining the effects of the loyalty perceptions of the fans on purchasing behavior by logistic regression analysis. International Journal of Management Economics and Business, 15(2), 532-541.Available at: $10.17130 /$ ijmeb.2019252109.

Etikan, I., Musa, S. A., \& Alkassim, R. S. (2016). Comparison of convenience sampling and purposive sampling. American Journal of Theoretical and Applied Statistics, 5(1), 1-4.Available at: https://doi.org/10.11648/j.ajtas.20160501.11.

Farzin, M., \& Fattahi, M. (2018). eWOM through social networking sites and impact on purchase intention and brand image in Iran. Journal of Advances in Management Research, 15(2), 151-183.Available at: https://doi.org/10.1108/jamr-05-2017-0062.

Felix, R., Rauschnabel, P. A., \& Hinsch, C. (2017). Elements of strategic social media marketing: A holistic framework. Journal of Business Research, $70(7), 118-126$. Available at: https://doi.org/10.1016/j.jbusres.2016.05.001.

Firat, N., \& Barut, Y. (2018). Development of social media addiction scale: Validity and reliability study. Journal of Human Sciences, 15(4), 2266-2279.Available at: https://doi.org/10.14687/jhs.v15i4.5181.

Frutos, S. M., Giones, F., \& Miralles, F. (2014). Social media engagement as an e-commercedriver, a consumer behavior perspective. Paper presented at the In 2014 9th Iberian Conference on Information Systems and Technologies (CISTI). IEEE.

George, D., \& Mallery, M. (2010). SPSS for windows step by step: A simple guide and reference, 17.0 update (10th ed.). Boston: Pearson.

Grau, S., Kleiser, S., \& Bright, L. (2019). Exploring social media addiction among student millennials. Qualitative Market Research: An International Journal, 22(2), 200-2 16.Available at: https://doi.org/10.1108/qmr-02-2017-0058.

Griffiths, M., \& Kuss, D. (2017). Adolescent social media addiction (revisited). Education and Health, 35(3), 49-52.

Hancock, A. M., Jorgensen, B. L., \& Swanson, M. S. (2013). College students and credit card use: The role of parents, work experience, financial knowledge, and creditcard attitudes. Journal of family and Economi Cissues, 34(4), 369-381.Available at: 10.1007/s 10834012-9338-8.

Hawi, N. S., \& Samaha, M. (2017). The relations among social media addiction, self-esteem, and life satisfaction in university students. Social Science Computer Review, 35(5), 576-586.Available at: https://doi.org/10.1 177/0894439316660340.

Hoffman, D. L., \& Novak, T. P. (1996). Marketing in hypermedia computer-mediated environments: Conceptual foundations. Journal of Marketing, 6O(3), 50-68.Available at: https://doi.org/10.2307/1251841.

Jamil, R. A., \& Rameez, u. H. S. (2014). Influence of celebrity endorsement on consumer purchase intention for existing products: A comparative study. Journal of Management Info, 4(1), 1-23.

Kaplan, A. M., \& Haenlein, M. (2010). Users of the world, unite! the challenges and opportunities of social media. Business Horizons, 53(1), 59-68.Available at: http://dx.doi.org/10.1016/j.bushor.2009.09.003.

Kemp, S. (2020). Digital 2020: Global digital yearbook-we are social. USA: Hootsuite.

Kim, B., \& Kim, Y. (2019). Growing as social beings: How social media use for college sports is associated with college students' group identity and collective self-esteem. Computers in Human Behavior, 97(2), 241-249.Available at: https://doi.org/10.1016/j.chb.2019.03.016.

Kircaburun, K. (2016). Self-Esteem, daily internet use and social media addiction as predictors of depression among Turkish adolescents. Journal of Education and Practice, 7(24), 64-72. 
Koçarslan, H., \& Kılınç, H. (2019). Consumer perception in digital marketing, . A Research on Internet Shopping, 9(17), $1263-1273$.

Koufaris, M. (2002). Applying the technology acceptance model and flow theory to online consumer behavior. Information Systems Research, 13(2), 205-223.Available at: https://doi.org/10.1287/isre.13.2.205.83.

Krasnova, H., Veltri, N. F., Eling, N., \& Buxmann, P. (2017). Why men and women continue to use social networking sites: The role of gender differences. The Journal of Strategic Information Systems, 26(4), 261-284.Available at: https://doi.org/10.1016/j.jsis.2017.01.004. S. Strategic Information Systems, 26(4), 261-284.Available

Kumar, V., Varma, M., Sangvikar, B., \& Pawar, A. (2020). Realising the transformation of customer purchase behaviour: Assessment of impact of social media on purchasing behavior of consumers in India. Test Engineering and Management, 82(Jan/Feb 2020), 1299012998.

Kuss, D. J., Griffiths, M. D., Karila, L., \& Billieux, J. (2014). Internet addiction: A systematic review of pidemiological research for the last decade. Current Pharmaceutical Design, 20, 4026-4052.Available at: https://doi.org/10.2174/13816128113199990617.

Kuss, D. J., \& Griffiths, M. D. (2017). Social networking sites and addiction: Ten lessons learned. International Journal of Environmental Research and Public Health, 14(3), 2-17.Available at: https://doi.org/10.3390/ijerph14030311.

Lam, A. Y., Lau, M. M., Cheng, C., \& Wong, M. Y. (2019). The impact of electronic word-of-mouth on young consumers' purchase intention in Hong Kong. Paper presented at the In Proceedings of the 10th International Conference on E-Education, E-Business, E-Management and E-Learning.

Lim, X. J., Radzol, A. M., Cheah, J., \& Wong, M. (2017). The impact of social media influencers on purchase intention and the mediation effect of customer attitude. Asian Journal of Business Research, 7(2), 19-36.

Liu, Y., Li, H., \& Hu, F. (2013). Website attributes in urging online impulse purchase: An empirical investigation on consumer perceptions. Decision Support Systems, 55(3), 829-837.Available at: https://doi.org/10.1016/j.dss.2013.04.001.

Longstreet, P., \& Brooks, S. (2017). Life satisfaction: A key to managing internet \& social media addiction. Technology in Society, 50, 7377.Available at: https://doi.org/10.1016/j.techsoc.2017.05.003.

Martyn, J., Fowler, B., Kropp, D. C., Oja, B. D., \& Bass, J. R. (2019). Managing an identity: Social Identity complexity and NCAA faculty athletics representatives. Journal of Issues in Intercollegiate Athletics, 12(24), 365-383.

Mazlum, M. M., \& Mazlum, A. A. (2017). Determination of research method in social sciences. Route Educational and Social Science Journal, 4(4), 1-21.Available at: 10.17121/ressjournal.705.

McGregor, S. C., Lawrence, R. G., \& Cardona, A. (2017). Personalization, gender, and social media: Gubernatorial candidates' social media strategies. Information, communication \& society, 20(2), 264-283.

Meydan, B., \& Tunca, M. Z. (2019). A study on the effects of social media on hedonic purchasing behavior-A study on the effects of social media over hedonic shopping behaviors. Mehmet Akif Ersoy University Journal of Social Sciences Institute, 10(26), 832-854.Available at: https://doi.org/10.20875/makusobed.466233.

Naylor, R. W., Lamberton, C. P., \& West, P. M. (2012). Beyond the "like" button: The impact of mere virtual presence on brand evaluations and purchase intentions in social media settings. Journal of Marketing, 76(6), 105-120.Available at: https://doi.org/10.1509/jm.11.0105.

Nevin, S., Gleasure, R., O'Reilly, P., Feller, J., Li, S., \& Cristoforo, J. (2017). Social identity and social media activities in equity crowd funding. Paper presented at the In Proceedings of the 13 th International Symposium on Open Collaboration.

Novak, T. P., Hoffman, D. L., \& Yung, Y.-F. (2000). Measuring the customer experience in online environments: A structural modeling approach. Marketing Science, 19(1), 22-42.Available at: https://doi.org/10.1287/mksc.19.1.22.15184.

Pomirleanu, N., Schibrowsky, J. A., Peltier, J., \& Nill, A. (2013). A review of internet marketing research over the past 20 years and future research direction. Journal of Research in Interactive Marketing, 7(3), 166.Available at: https://doi.org/10.1 108/jrim-01-2013-0006.

Rialti, R., Zollo, L., Pellegrini, M. M., \& Ciappei, C. (2017). Exploring the antecedents of brand loyalty and electronic word of mouth in social-media-based brand communities: do gender differences matter? Journal of Global Marketing, 30(3), 147-160.Available at: https://doi.org/10.1080/08911762.2017.1306899.

Rook, D. W. (1987). The buying impulse. Journal of Consumer Research, 14(2), 189-199.

Ryan, T., Chester, A., Reece, J., \& Xenos, S. (2014). Theuses and abuses of facebook: A review of facebook addiction. Journal of Behavioral Addictions, 3, 133-148.Available at: https://doi.org/10.1556/JBA.3.2014.016.

Santos., B. D., Mendes-Da, S. W., Flores, E., \& Norvilitis, J. M. (2016). Predictors of credit card use and perceived financial well-being in female college students: A B razil-U nited S tates comparative study. International Journal of Consumer Studies, 40(2), 133142.Available at: https://doi.org/10.1111/ijcs.12234.

Santoso, S., \& Oetomo, B. S. D. (2019). Structural relationship between social benefit, dependency, satisfaction, and habit formation on the use of social media. Binus Business Review, 10(1), 51-57.Available at: https://doi.org/10.21512/bbr.v 10i1.5407.

Savci, M., \& Aysan, F. (2017). Technological addictions and social connectedness: predictor effect of internet addiction, social media addiction, digital game addiction and smartphone addiction on social connectedness. Dusunen Adam: Journal of Psychiatry $\mathscr{E}^{\circ}$ Neurological Sciences, 30(3), 202-2 17.Available at: https://doi.org/10.5350/dajpn2017300304.

Schivinski, B., \& Dabrowski, D. (2016). The effect of social media communication on consumer perceptions of brands. Journal of Marketing Communications, 22(2), 189-2 14.Available at: https://doi.org/10.1080/13527266.2013.871323.

Shah, A. M., Zahoor, S. Z., \& Qureshi, I. H. (2019). Social media and purchasing behavior: A study of the mediating effect of customer relationships. Journal of Global Marketing, 32(2), 93-115.Available at: https://doi.org/10.1080/0891 1762.2018.1497243.

Shankar, M. (2012). A harbinger of change: Internet marketing and E-commerce. Indian Streams Research Journal, $2(4), 1-3$.

$\mathrm{Si}, \mathrm{S}$. (2016). Social media and its role in marketing. Business and Economics Journal, 7(1), 1-5.Available at: 10.4172/2151-6219.1000203.

Smith, D. N., \& Sivakumar, K. (2004). Flowand Internet shopping behavior: A conceptual model and research propositions. Journal of Business Research 57(10), 1199-1208.

Solomon, M., Bamossy, G., Askegaard, S., \& Hogg, M. K. (2006). Consumer behaviour: A European perspective. Edinburgh Gate, Harlow, Essex CM20 2JE, England: Pearson Education Limited.

Stern, H. (1962). The significance of impulse buying today. Journal of Marketing, 26(2), 59-62.Available at: https://doi.org/10.2307/1248439.

Swar, B., \& Hameed, T. (2017). Fear of missingout, social media engagement, smartphone addiction and distraction: Moderating role of self-help mobile apps-based Interventions in the Youth. Paper presented at the 10th International Joint Conference on Biomedical Engineering Systems and Technologies, Proceedings Book: HEALTHINF: Portugal.

Thadani, D. R., Cheung, C. M., \& Lee, Z. W. (2016). Social networking site addiction: The cognitive bias perspective. Paper presented at the Pacific Asia Conference on Information Systems (PACIS - Proceedings). Summer 6-27-2016.

Thoumrungroje, A. (2014). The influence of social media intensity and EWOM on conspicuous consumption. Procedia-Social and Behavioral Sciences, 148, 7-15.Available at: https://doi.org/10.1016/j.sbspro.2014.07.009.

Tien, D. H., Rivas, A. A. A., \& Liao, Y.-K. (2019). Examining the influence of customer-to-customer electronic word-of-mouth on purchase intention in social networking sites. Asia Pacific Management Revier, 24(3), 238-249.Available at: https://doi.org/10.1016/j.apmrv.2018.06.003.

Turel, O., Brevers, D., \& Bechara, A. (2018). Time distortion when users at-risk for social media addiction engage in non-social media tasks. Journal of Psychiatric Research, 97, 84-88.Available at: https://doi.org/10.1016/j.jpsychires.2017.11.014.

Wang, T. (2017). Social identity dimensions and consumer behavior in social media. Asia Pacific Management Review, 22(1), 45-51.Available at: https://doi.org/10.1016/j.apmrv.2016.10.003.

Weinstein, A., \& Lejoyeux, M. (2010). Internet addiction or excessive internet use. The American Journal of Drug and Alcohol Abuse, 36(5), $277-283$.

Wölfling, K., Beutel, M., Dreier, M., \& Müller, K. (2014). Treatment outcomes in patients with internet addiction: A clinical pilot study on the effects of a cognitive-behavioral therapy program. BioMed Research International, 2014 (ID 425924).Available at: https://doi.org/10.1155/2014/425924.

Yang, S.-Y., Chen, M.-D., Huang, Y.-C., Lin, C.-Y., \& Chang, J.-H. (2017). Association between smartphone use and musculoskeletal discomfort in adolescent students. Journal of Community Health, 42(3), 423-430.Available at: https://doi.org/10.1007/s 10900-0160271-x. 
Yoldaş, M., \& Akın, M., S. (2019). An application to examine uncontrolled purchasing trends within the scope of electronic shopping. Hitit University Journal of Social Sciences Institute, 12(2), 430-446.Available at: 10.17218/hititsosbil.596267.

Yurtsever, S., \& Çakmak, A. Ç. (2012). The effect of credit card on impulse purchase: An application for the academic staff of Karabuk University. Journal of History Culture and Art Research, 1(4), 45-72.

Zainal, N. T. A., Harun, A., \& Lily, J. (2017). Examining the mediating effect of attitude towards electronic words-of mouth (eWOM) on the relation between the trust in eWOM source and intention to follow eWOM among Malaysian travellers. Asia Pacific Management Review, 22(1), 35-44.Available at: https://doi.org/10.1016/j.apmrv.2016.10.004. 